\title{
Yield of 'Prata-Anã' banana plants under water deficit and high plant density
}

\author{
Diogo Barreto Magalhães ${ }^{1}$, Sérgio Luiz Rodrigues Donato², Marcelo Rocha dos Santos², \\ Cleiton Fernando Barbosa Brito ${ }^{3}$, Varley Andrade Fonseca ${ }^{3}$, Bruno Soares de Souza ${ }^{1}$
}

\begin{abstract}
Yield-improving and water-saving techniques assume great importance in the cultivation of banana plants under semiarid regions, prone to greater climate variability. The objective of this study was to evaluate yield and water-use efficiency (WUE) response of 'Prata-Anã' banana plants to combinations of plant densities and irrigation levels: three irrigation levels, 50,75 and $100 \%$ crop evapotranspiration $(\mathrm{ETc})$, and four plant densities, 1,666 (3.0 × $2.0 \mathrm{~m}), 2,083(3.0 \times 1.6 \mathrm{~m}), 2,666$ $(3.0 \times 1.25 \mathrm{~m})$ and $3,333(3.0 \times 1.0)$ plants $\mathrm{ha}^{-1}$, evaluated in two production cycles. The treatments were laid out in a randomized block design with four replicates. Increasing plant density up to 3,333 plants ha ${ }^{-1}$ induced reductions in number of leaves at harvest and some yield components; also, longer cycles, and increased yields were observed while maintaining fruit marketable size, regardless of the irrigation level used. Using an irrigation level at $50 \% \mathrm{ETc}$ and a plant density of 3,333 plants ha ${ }^{-1}$ led to an increase in WUE of $313.92 \%$ in the first cycle and $295.27 \%$ in the second cycle compared with 1,666 plants ha-1 irrigated at $100 \%$ ETc. Higher yields and WUE can be achieved by using a plant population density of 3,333 plants ha-1 and irrigation levels below $100 \% \mathrm{ETc}$.
\end{abstract}

Index terms: Musa spp., water productivity, dense planting

\section{Produção de bananeira 'Prata-Anã' com déficit hídrico e alta densidade de plantio}

Corresponding author: diogobarretoif@gmail.com

Received: April 14, 2020 Accepted: June 15, 2020

Copyright: All the contents of this journal, except where otherwise noted, is licensed under a Creative Commons Attribution License.

\begin{abstract}
Resumo - Em condições semiáridas com maior variabilidade climática, é imperativo implementar estratégias de cultivo e de manejo de irrigação para aumentar a produtividade da bananeira com economia hídrica. Objetivou-se avaliar produção e eficiência de uso de água (EUA) da bananeira 'Prata-Anã' sob combinações de lâminas de irrigação e densidades de plantio. Os tratamentos foram: três lâminas de irrigação, $50 ; 75$ e $100 \%$ da evapotranspiração da cultura, ETc, quatro densidades de plantio, 1.666 (3,0 x 2,0 m), 2.083 (3,0 x 1,6 m), $2.666(3,0 \times 1,25 \mathrm{~m})$ e $3.333(3,0$ $\mathrm{x} 1,0)$ plantas $\mathrm{ha}^{-1}$ e dois ciclos de produção, dispostos em delineamento em blocos casualizados, com quatro repetições. $\mathrm{O}$ aumento da densidade de plantio até 3.333 plantas ha $^{-1}$ diminui o número de folhas na colheita, as características produtivas dos frutos, aumenta o período para colheita, mas eleva a produtividade e mantém a classificação comercial dos frutos, independentemente da lâmina de irrigação. A redução de $50 \%$ da ETc com aumento da densidade de plantio para 3.333 plantas ha $^{-1}$ proporciona aumento de $313,92 \%$ na EUA, no primeiro ciclo, e $295,27 \%$ no segundo ciclo. É possível obter maior produtividade e maior EUA com densidade de plantio de até 3.333 plantas $^{-1}$ e irrigação inferior a $100 \%$ da ETc.
\end{abstract}

Termos para indexação: Musa spp., produtividade da água, plantio adensado. 


\section{Introduction}

In irrigated fruit-growing areas in semiarid regions of Brazil, using water-saving irrigation strategies is critical to an environmentally sustainable production (SANTOS et al., 2019). This is particularly important for bananas, which need a constant, large supply of water throughout the year (TURNER et al., 2007).

Studies have been carried out investigating irrigation strategies (SANTOS et al., 2016) and deficit irrigation techniques (COELHO et al., 2019; SANTOS et al., 2019) in bananas. Increased water-use efficiency (WUE) may be achieved by associating yield-improving practices with water-saving irrigation strategies. Therefore, increasing the number of plants per unit area coupled with water-saving irrigation practices can be incorporated into banana production systems.

In semiarid conditions, a higher plant density prevents plants from damages caused by strong winds and excessive radiation, decreases weed population and herbicide use, improves cooling within banana plantations, reduces water evaporation from the soil, and increases WUE (DONATO et al., 2015; SANTOS et al., 2019). Additionally, increasing plant density contributes to the decrease in incidence of Black and Yellow Sigatokas and the fungicide use associated with them because Sigatokas are less severe under decreased sunlight ambient (CAVALCANTE et al., 2014).

However, plant responses to increased plant density are site-specific and related to interactions between soil, water, genotype and environment. Thus, studies on combining irrigation strategies with high plant population densities are needed for bananas grown in semiarid regions (SANTOS et al., 2019).
It is assumed that increasing plant density while applying less water than the evapotranspiration demand of plants will lead to changes in soil water content that, in turn, may affect the water status, growth, development and yields of banana plants. Certain combinations may help in decreasing water use by plants while maintaining or increasing yields, thereby improving WUE.

Efficient practices are critical to maintaining the sustainability of banana plantations; thus, studies on combining different crop practices are relevant to the strengthening of information transferred to banana growers, in addition to improving recommendations for water-efficient, high-yielding crop production systems.

Increasing WUE can be attained by: (i) increased yield as a result of increased plant density while the amount of water applied remains the same; (ii) less water is applied while plant density and yield remain the same; or (iii) increased yield as a result of increased plant density while decreasing the amount of water applied. Therefore, the objective was to evaluate how combinations of plant densities and irrigation levels affect yield and WUE of 'Prata-Anã' banana plants grown under semiarid climate.

\section{Material and methods}

A field experiment was carried out on an experimental area at the Instituto Federal Baiano, campus Guanambi, southwestern Bahia, Brazil (14 $14^{\circ}$ 'S, $42^{\circ} 46^{\prime} \mathrm{W}$, and altitude of $545 \mathrm{~m}$ ). The climate of the region is hot and dry semiarid with mean annual temperature and precipitation of $25.6{ }^{\circ} \mathrm{C}$ and $680 \mathrm{~mm}$, respectively. Rains occur mostly between November and March (Figure 1).

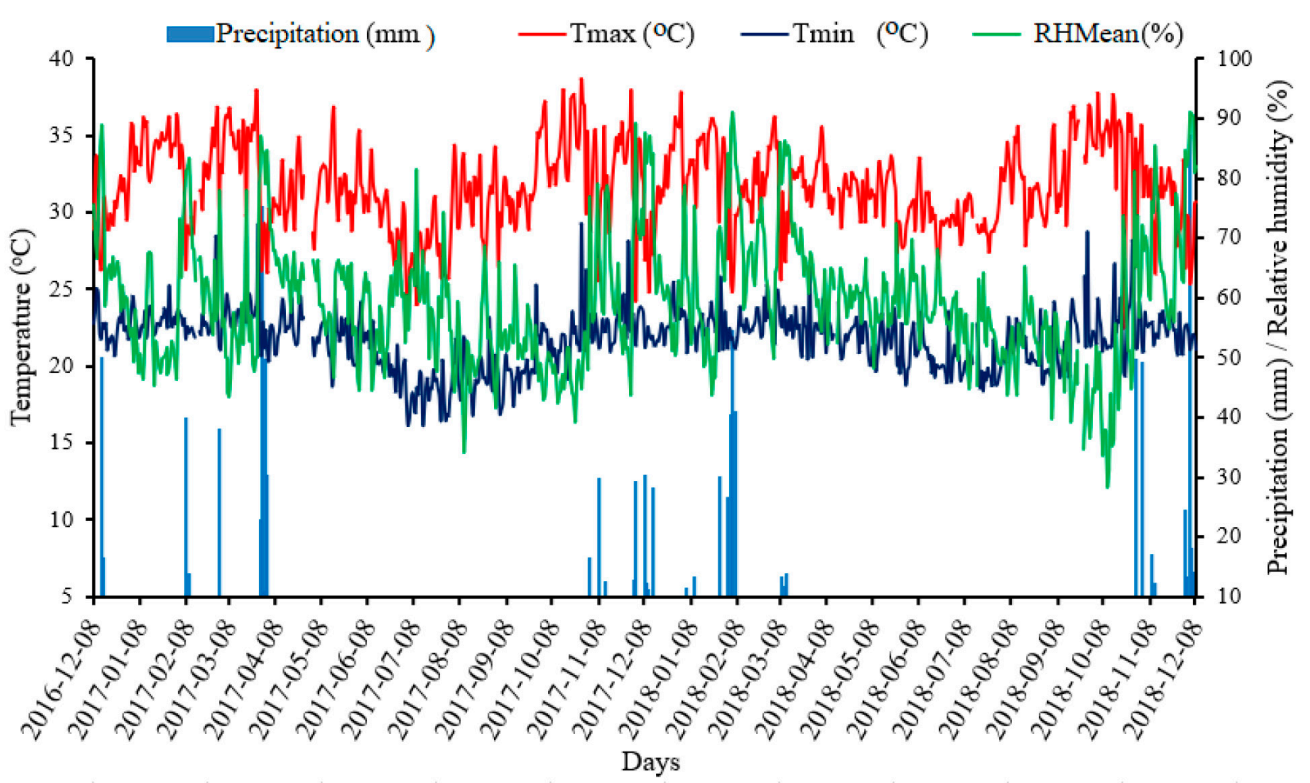

Figure 1. Daily climate data recorded during the experiment. Note: Tmax, maximum temperature; Tmin, minimum temperature; RHmean, mean relative humidity. Data collected by an automatic weather station installed close to the experimental area at the Instituto Federal Baiano 
The experiment comprised two production cycles, from December 2016 to December 2018, of micro-sprinkle irrigated banana cultivar Prata-Anã (AAB).
The soil was classified originally as a typical dystrophic medium-textured Red-Yellow Latosol with weak A horizon (EMBRAPA, 2013). However, after 20 years of successive soil amendment and fertilizer applications, the soil assumed enhanced fertility (MARQUES et al., 2018), with mean base saturation at 93\% (Table 1).

Table 1. Soil chemical properties before establishing the banana plantation. Guanambi, BA, 2016

\begin{tabular}{|c|c|c|}
\hline \multirow{2}{*}{ Property } & \multicolumn{2}{|c|}{ Depth $(\mathrm{cm})$} \\
\hline & $0.00-0.20$ & $0.20-0.40$ \\
\hline $\mathrm{pH}^{1}$ & 7.8 & 7.6 \\
\hline $\mathrm{SOM}^{2}\left(\right.$ dag $\left._{\mathrm{kg}^{-1}}\right)$ & 2.1 & 0.7 \\
\hline $\mathrm{P}^{3}\left(\mathrm{mg} \mathrm{dm}^{-3}\right)$ & 467.8 & 208.9 \\
\hline $\mathrm{K}^{3}\left(\mathrm{mg} \mathrm{dm}^{-3}\right)$ & 598.5 & 351.8 \\
\hline $\mathrm{Na}^{3}\left(\mathrm{cmol}_{\mathrm{c}} \mathrm{dm}^{-3}\right)$ & 0.2 & 0.2 \\
\hline $\mathrm{Ca}^{4}\left(\mathrm{cmol}_{\mathrm{c}} \mathrm{dm}^{-3}\right)$ & 5.6 & 3.7 \\
\hline $\mathrm{Mg}^{4}\left(\mathrm{cmol}_{\mathrm{c}} \mathrm{dm}^{-3}\right)$ & 2.5 & 1.8 \\
\hline $\mathrm{Al}^{4}\left(\mathrm{cmol}_{\mathrm{c}} \mathrm{dm}^{-3}\right)$ & 0.0 & 0.0 \\
\hline $\mathrm{H}+\mathrm{Al}^{5}\left(\mathrm{cmol}_{\mathrm{c}} \mathrm{dm}^{-3}\right)$ & 0.7 & 0.8 \\
\hline $\mathrm{SB}\left(\mathrm{cmol}_{\mathrm{c}} \mathrm{dm}^{-3}\right)$ & 9.9 & 6.6 \\
\hline $\operatorname{ECEC~}\left(\mathrm{cmol}_{\mathrm{c}} \mathrm{dm}^{-3}\right)$ & 9.9 & 6.6 \\
\hline $\mathrm{CEC}\left(\mathrm{cmol}_{\mathrm{c}} \mathrm{dm}^{-3}\right)$ & 10.6 & 7.3 \\
\hline $\mathrm{V}(\%)$ & 93 & 89 \\
\hline $\mathrm{B}^{6}\left(\mathrm{mg} \mathrm{dm}^{-3}\right)$ & 0.9 & 1.0 \\
\hline $\mathrm{Cu}^{3}\left(\mathrm{mg} \mathrm{dm} \mathrm{m}^{-3}\right)$ & 1.2 & 2.0 \\
\hline $\mathrm{Fe}^{3}\left(\mathrm{mg} \mathrm{dm}{ }^{-3}\right)$ & 15.6 & 16.3 \\
\hline $\operatorname{Mn}^{3}\left(\mathrm{mg} \mathrm{dm}^{-3}\right)$ & 115.4 & 71.5 \\
\hline $\mathrm{Zn}^{3}\left(\mathrm{mg} \mathrm{dm} \mathrm{m}^{-3}\right)$ & 30.6 & 12.4 \\
\hline $\mathrm{P}_{\mathrm{rem}}{ }^{8}\left(\mathrm{mg} \mathrm{L}^{-1}\right)$ & 46.7 & 42.8 \\
\hline $\mathrm{EC}\left(\mathrm{dS} \mathrm{m} \mathrm{m}^{-1}\right)$ & 1.7 & 1.1 \\
\hline
\end{tabular}

Note: ${ }^{1 / \mathrm{pH}}$ in water; ${ }^{2 /}$ Calorimetry; ${ }^{3 /}$ Mehlich-1 extractor; ${ }^{4 / \mathrm{KCl}} 1 \mathrm{~mol} / \mathrm{L} ;{ }^{5 /} \mathrm{SMP}$ buffer method; ${ }^{6} \mathrm{CaCl}_{2} ;{ }^{7 /} \mathrm{Ca}\left(\mathrm{H}_{2} \mathrm{PO}\right)_{2}, 500 \mathrm{mg} / \mathrm{L}$ of P in $\mathrm{HOAc} 2$ $\mathrm{mol} / \mathrm{L} ;{ }^{8 /}$ Equilibrium P solution; SOM, soil organic matter; SB, sum of bases; ECEC, effective cation exchange capacity; CEC, cation exchange capacity at $\mathrm{pH}$ 7; V, base saturation; $\mathrm{m}$, aluminum saturation; P-rem, remaining phosphorus; EC, electrical conductivity.

Micropropagated, acclimated banana plantlets were used. Cultivation practices were based on recommendations for bananas (RODRIGUES et al., 2015). Prior to planting, the area was conventionally tilled (subsoiling, plowing and harrowing) and furrows were made at $3.0 \mathrm{~m}$ apart. Planting holes measuring $0.5 \times 0.4 \times 0.4 \mathrm{~m}$ were dug using an auger attached to a tractor.

NPK fertilizers were top dressed as recommended by Silva (2015) with modifications based on soil and leaf tissue tests made during the cycles. Whenever needed, micronutrient fertilizers were applied via the rhizome of a removed sucker (RODRIGUES et al., 2007).
Treatments were the combination of three irrigation levels: 50, 75 and 100\% crop evapotranspiration (ETc); four plant densities: 1,666 (3.0 x $2.0 \mathrm{~m}), 2,083(3.0 \times 1.6$ $\mathrm{m}), 2,666(3.0 \times 1.25 \mathrm{~m})$, and 3,333 (3.0 x 1.0) plants $\mathrm{ha}^{-1}$; and two production cycles: first and second cycles (mother-plant and daughter-plant cycles, respectively). The treatments were laid out in a randomized block design with four replicates, and evaluated following a split-split plot design: irrigation levels were assigned to plots, plant densities to sub-plots, and production cycles to sub-sub plots. Each experimental plot, of a total of 48 , consisted of 16 plants arranged in a $4 \times 4$ format; measurements were taken from the four plants located in the center of the plot while the surrounding plants were border. 
Plants were irrigated with micro-sprinklers (Amanco ${ }^{\circledR}$ ) with flow rate of $120 \mathrm{~L} \mathrm{~h}^{-1}$ at an operating pressure of $200 \mathrm{kPa}$, spaced $4.0 \mathrm{~m}$ apart on a $40 \mathrm{~m}$ long lateral. The laterals were $6.0 \mathrm{~m}$ apart and had eight emitters. Flow rate and application efficiency were measured during the experiment, assuming values of $116.22 \mathrm{~L} \mathrm{~h}^{-1}$ and $82.80 \%$, respectively.

Irrigation scheduling was based on crop evapotranspiration (ETc), which is the product of daily reference evapotranspiration (ETo) and crop coefficient $(\mathrm{Kc})$. Daily ETo was indirectly determined by the method of Penman-Monteith (ALLEN et al., 1998), calculated daily based on data by an automatic weather station (Vantage Pro Integrated Sensor, Davis Instruments, Wayward, Ca, USA) installed $100 \mathrm{~m}$ from the experimental area.

The values of Kc used to calculate ETc was estimated using the equation proposed by Borges et al. (2011): $\mathrm{Kc}=0.704-6.443 \times 10^{-3} \mathrm{DAP}+6.437 \times 10^{-5}$ $\mathrm{DAP}^{2}-1.1174 \times 10^{-7} \mathrm{DAP}^{3} ; \mathrm{R}^{2}=0.978$. From planting to 120 days after planting (DAP), irrigation water was evenly applied to all treatments. The equation estimated $\mathrm{Kc}$ values ranging from 0.5 to 1.4 from 120 DAP to 296 DAP, from then on the Kc value stabilized at 1.4.

Measurements were taken at flowering and harvest of the first (mother-plant cycle) and second production cycle (daughter-plant or ratoon cycle).

The following were measured at the flowering stage of each cycle: number of days to flowering (period between planting and flowering); plant height, corresponding to the length of the pseudostem $(\mathrm{cm})$; pseudostem girth at soil level $(\mathrm{cm})$, number of leaves; total leaf area $\left(\right.$ TLA $\left.-\mathrm{m}^{2}\right)$, estimated following the method used by Oliveira et al. (2013): TLA $=0.5789 \times$ L x W x NL; where L and W are, respectively, length and width of the third leaf, NL is number of leaves, and 0.5789 is a correction factor. In addition, leaf area index (LAI) $\left(\mathrm{m}^{2} \mathrm{~m}^{-2}\right)$ was determined as the ratio of TLA to the area occupied by the plant on the soil surface. Only living, functional leaves of a representative plant, with at least half of the leaf surface area undamaged, were used when measuring leaf area.

The following were measured at harvest: number of leaves, bunch weight $(\mathrm{kg})$, hand weight $(\mathrm{kg})$, hand number, number of fruits, mean fruit weight $(\mathrm{g})$, number of days to harvest (period from planting to harvest), outer fruit length $(\mathrm{cm})$, fruit diameter $(\mathrm{mm})$, hand yield $\left(\mathrm{t} \mathrm{ha}^{-1}\right)$, and WUE $\left(\mathrm{kg} \mathrm{ha}^{-1} \mathrm{~mm}^{-1}\right)$, which is the ratio of yield to total amount of water applied.

Following normality and homoscedasticity testing, the data were tested by analysis of variance to detect significant interactions between factors and differences across main factors. Regression models were fitted to significant two-way interactions, with plant density as a function of irrigation level and production cycles, and surface response model was fitted to significant threeway interactions, with plant densities and irrigation levels as a function of production cycles. If there were no interactions, the main effect of plant density on response variables was studied using regression analysis and means were separated using Tukey test $(\mathrm{p} \leq 0.05)$

Regression models were selected based on beta coefficients of t-tests, coefficient of determination and how well the model fitted the data.

\section{Results and Discussion}

Plant density and production cycle influenced the number of days to flowering, pseudostem girth, number of leaves, total leaf area, and LAI of 'Prata-Anã' banana plants at the flowering stage of the first and second production cycle, whereas irrigation levels influenced only total leaf area (Figure 2). All variables measured at flowering were influenced by production cycle. This was expected because daughter-plants (follower) generally grow more vigorous than mother-plants (ARANTES et al., 2017).

As the intervals between plant densities are not uniform, we used an interval of 556 plants, which is the average difference between plant densities, to make it easier to illustrate the response of dependent variables to plant density. A linear model was fitted to the relationship between the number of days to flowering and plant density. The model predicts an increase of 4.19 and 26.61 days for every 556 plants added to the stand in the first and second production cycle, respectively (Figure 2A). Increasing plant density from 1,666 to 3,333 plants ha ${ }^{-1}$ resulted in increases of 5.54 and $16.58 \%$ in the number of days to flowering in the first and second production cycle, respectively. Plants taking longer to flower in the second cycle might be due to the increased shading.

The number of days to flowering is counted from planting to the flowering. The daughter-plant was selected 150 days after planting when suckers were at least $30 \mathrm{~cm}$ high or approximately 30 days old; thus, to estimate how long it took for daughter-plants to flower, 120 is subtracted from the number of days to flowering because daughterplants are roughly 120 days younger than mother-plants. For 1,666 plants ha ${ }^{-1}$, daughter-plants flowered when they were 361 days old, and for 3,333 plants ha-1 ${ }^{-1}$ flowering took place when daughter-plants were 440 days old. Nonetheless, plants took longer to flower in the second production cycle (ratoon cycle) because the follower remained shaded by the mother-plant, and this shading effect is increased by a higher plant density; this might explain why the highest plant density had a greater influence on the number of days to flowering in the second cycle than in the first cycle. 

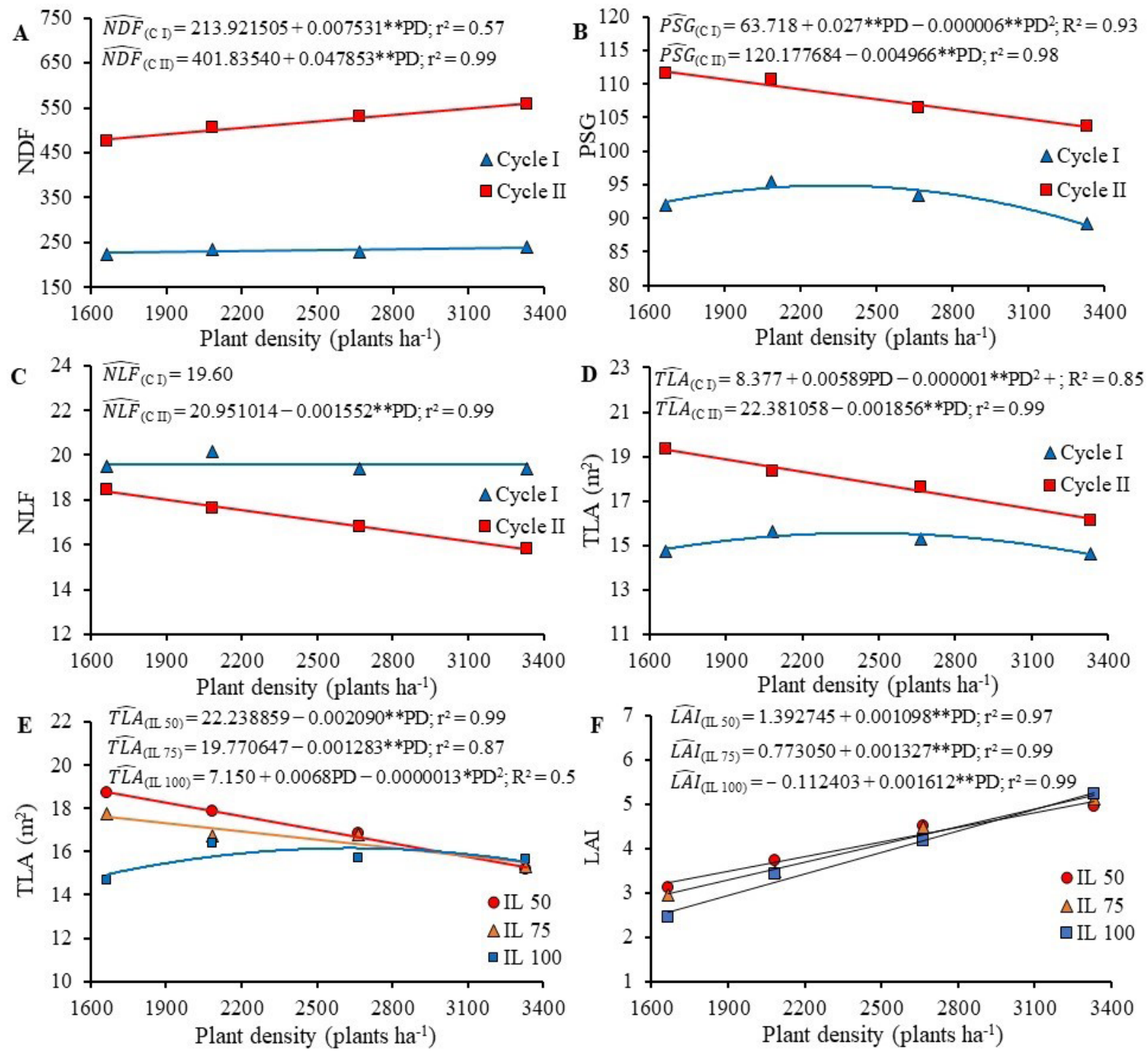

Figure 2. Cycle length and vegetative traits measured at flowering stage of 'Prata-Anã' banana plants grown in different plant densities $\left(1,666 ; 2,083 ; 2,666\right.$ and 3,333 plants ha $\left.{ }^{-1}\right)$, irrigation levels $(100,75$ and $50 \% \mathrm{ETc})$, and production cycles (mother- and daughter-plant). Note: number of days to flowering (A), pseudostem girth at soil level (B), number of leaves at flowering $(\mathrm{C})$, total leaf area $(\mathrm{D}$ and $\mathrm{E}$ ), leaf area index $(\mathrm{F}) . *$ significant at $5 \%$ and $* *$ significant at $1 \%$ by t-test.

In the first production cycle, a decreasing quadratic model was fitted to the response of pseudostem girth at soil level to plant density. The model estimates the highest pseudostem girth as $91.89 \mathrm{~cm}$ for a plant density of 2,166.67 plants ha- 1 . In the second cycle, the fitted model predicts a $7.40 \%$ decrease in pseudostem girth when increasing plant density from 1,666 to 3,333 plants ha-1 (Figure 2B). In the first production cycle, the number of leaves at flowering averaged 19.60 leaves per plant; in the second cycle, a linear reduction of $14.59 \%$ was observed, with a decrease of 0.5 leaf for every 556 plants added to the stand of plants (Figure 2C).

Cycle x plant density and irrigation level x plant density interactions influenced total leaf area (TLA), data of which followed a quadratic pattern in the first cycle and a linear pattern in the second cycle (Figure 2D). In the first cycle, the highest TLA was estimated at $15.63 \mathrm{~m}^{2}$ for $2,458.33$ plants ha $^{-1}$. In the second cycle, the model estimates decreases of $1.03 \mathrm{~m}^{2}$ for every 556 plants added to a stand containing 1,666 plants $\mathrm{ha}^{-1}$, representing a fall of $16.04 \%$. At irrigation level of $100 \%$ ETc, the lowest TLA was $16.17 \mathrm{~m}^{2}$ for $2,634.62$ plants ha ${ }^{-1}$.

As for irrigation levels, TLA had a decreasing quadratic response to $100 \%$ ETc and a decreasing linear response to irrigation levels at 50 and $75 \%$ ETc (Figure $2 \mathrm{E})$. The fitted models for irrigation levels at $50 \%$ and $75 \%$ ETc estimate decreases of 1.16 and $0.71 \mathrm{~m}^{2}$ for every 556 plants added, which results in decreases of $18.58 \%$ and $12.13 \%$ in TLA, respectively.

Increasing linear models were fitted to the response of LAI to irrigation levels at 50, 75 and $100 \%$ ETc as a function of plant density (Figure 2F). For a plant density of 1,666 plants ha-1 ${ }^{-1}$ LAI values increased from 3.22, 2.98 and $2.57 \mathrm{~m}^{2} \mathrm{~m}^{-2}$ to $5.05,5.20$ and $5.26 \mathrm{~m}^{2} \mathrm{~m}^{-2}$ when raising plant density from 1,666 to 3.333 plants ha ${ }^{-1}$ for irrigation levels at 50,75 and $100 \%$ ETc, respectively; in terms of percentage, these changes corresponded to increases of $56.81,74.14$ and $104.43 \%$. Leaf area indexes between 4 
and $5 \mathrm{~m}^{2} \mathrm{~m}^{-2}$ resulted from increased plant density allow plants to intercept $95 \%$ of the photosynthetically active radiation (TURNER et al., 2007), positively affecting yield (PEREIRA et al., 2000; SCARPARE FILHO; KLUGE, 2001; ROSALES et al., 2008, CAVALCANTE et al., 2014; ULLOA CORTAZAR et al., 2017; PRATA et al., 2018) as well as controlling weeds (LANZA et al., 2017; ULLOA CORTAZAR et al., 2017) and Sigatokas (CAVALCANTE et al., 2014) due to increased shading.
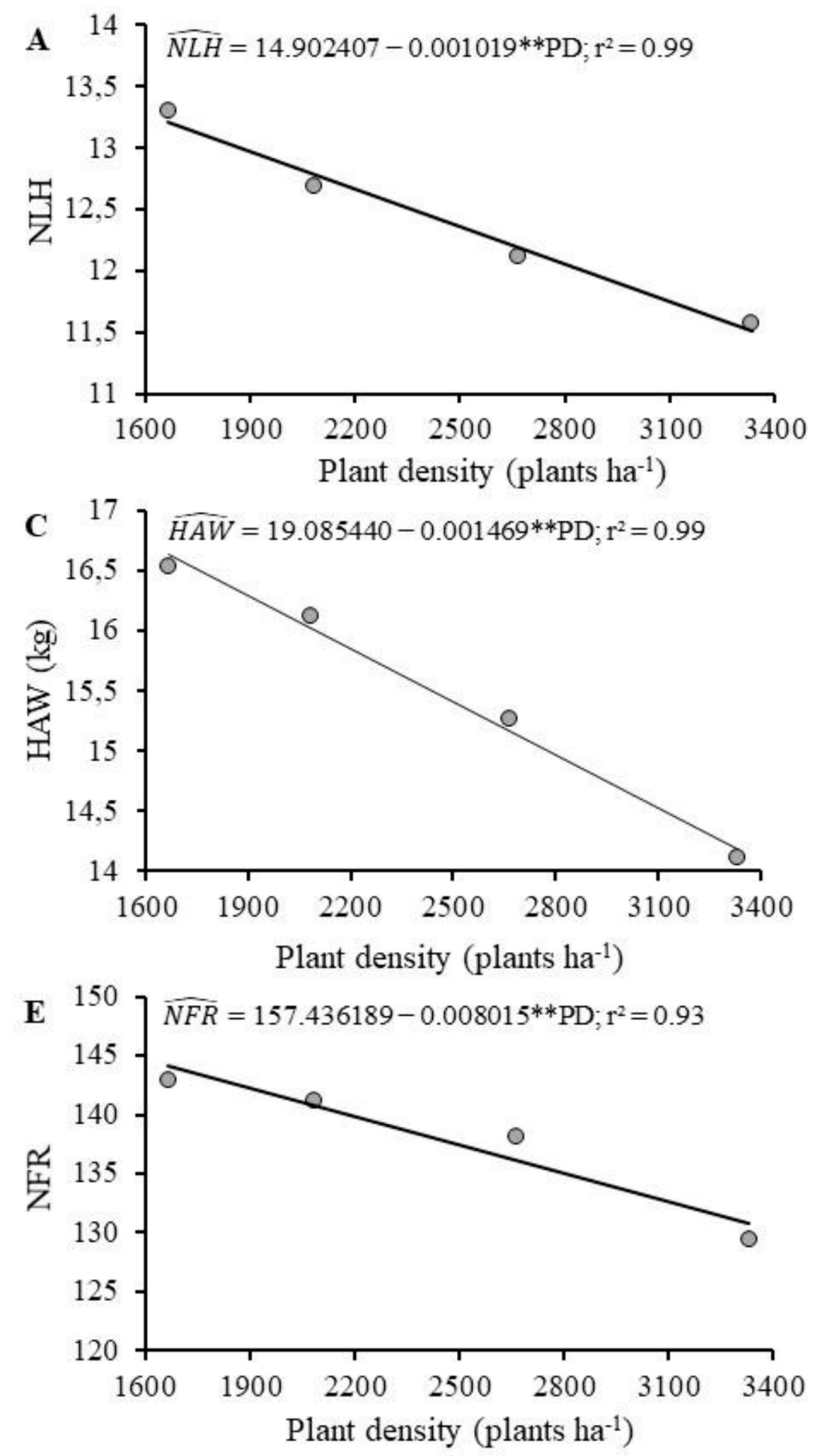

At harvest in the first and second cycles, plant density affected number of leaves at harvest, bunch weight, hand weight, number of fruits and mean fruit weight, all of which linearly decreased with increasing plant density (Figure 3). The higher competition among plants for space, water, nutrients and light explains these reductions. In doubling plant population density, the soil surface area available to the plant reduces by half, from 6 to $3 \mathrm{~m}^{2}$.
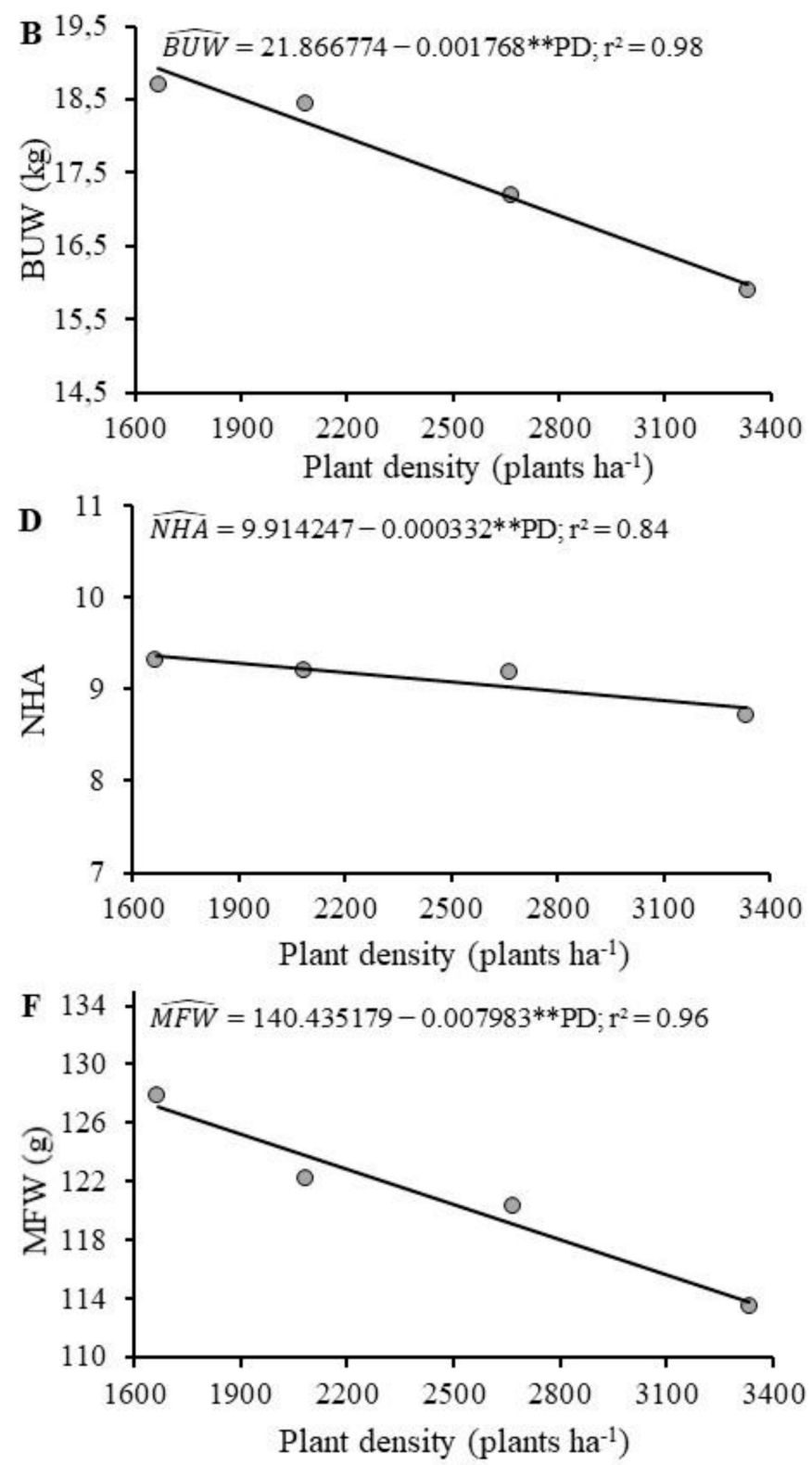

Figure 3. Vegetative traits and yield measured at harvest of 'Prata-Anã' grown at different plant densities $(1,666$; 2,$083 ; 2,666$ and 3,333 plants $^{-1} a^{-1}$, irrigation levels (100,75 and 50\% of crop evapotranspiration (ETc), and production cycles (mother- and daughter-plant). Note: Number of leaves at harvest (A), bunch weight (B), hand weight (C), number of hands (D), number of fruits (E), mean fruit weight (F). * significant at $5 \%$ and ** significant at $1 \%$ based on a t-test. 
When plant density is raised from 1,666 to 3,333 plants $\mathrm{ha}^{-1}$, the number of leaves, hands and fruits are estimated to reduce by $12.86,5.91$ and $9.27 \%$, which corresponded to decreases from 13.21 to 11.51 leaves, 9.36 to 8.81 hands and 144.08 to 130.72 fruits, and, consequently, the mean weigh of fruits, hands and bunch decreased. Bunch weight fell from $18.92 \mathrm{~kg}$ to $15.97 \mathrm{~kg}$, i.e., a decrease of $15.58 \%$ when using 3,333 plants ha ${ }^{-1}$ instead of 1,666 plants ha ${ }^{-1}$.
Despite the above, the highest plant population resulted in a linear increase in yield, from $28.23 \mathrm{t} \mathrm{ha}^{-1}$ to $47.64 \mathrm{t} \mathrm{ha}^{-1}$, an increase of $68.76 \%$ (Figure 4A). Based on fitted models, an increment of $6.47 \mathrm{t} \mathrm{ha}^{-1}$ is expected for every 556 plants added to the stand of banana plants; however, it is also expected that decreases of $0.82 \mathrm{~kg}$ in hand weight per bunch, $4.44 \mathrm{~g}$ in fruit weight, and 4.46 fruits for every 556 plants added. Higher competition for water, nutrients and sunlight among plants at a higher plant density reduces number and weight of fruits and hands, but the benefits of using higher plant populations outweigh these reductions by yielding more fruits per unit area. Similar results have been reported for several banana cultivars including Prata (PEREIRA et al., 2000), Cavendish (SCARPARE FILHO; KLUGE, 2001), Plantains (ROSALES et al., 2008; CAVALCANTE et al., 2014; ULLOA CORTAZAR et al., 2017; PRATA et al., 2018), and 'BRS Platina' (SANTOS et al., 2019).
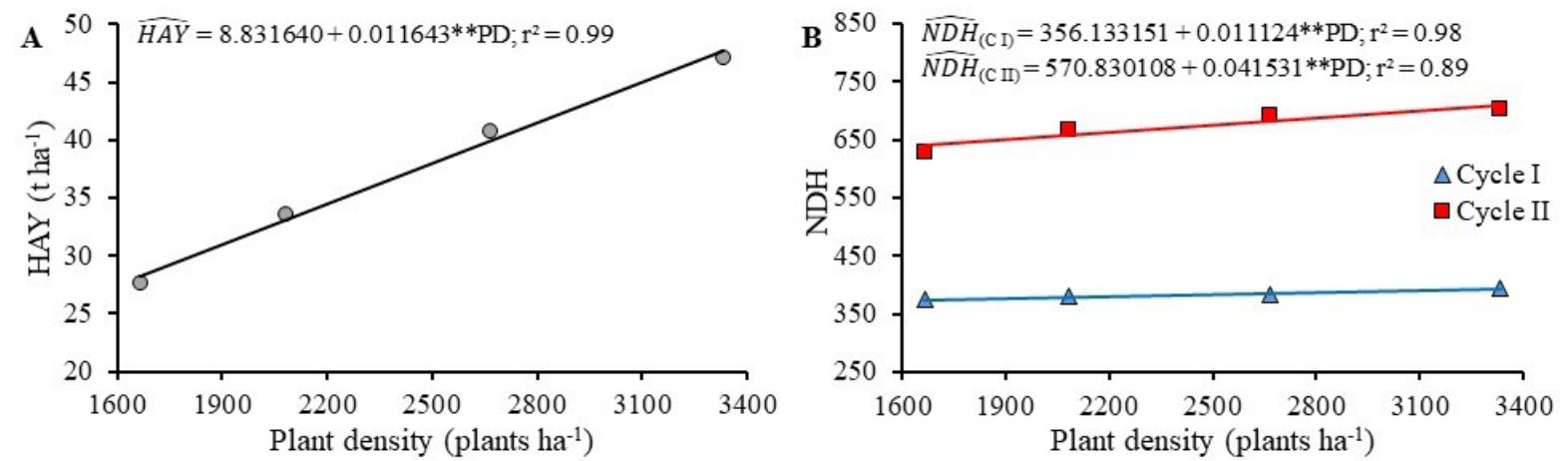

Figure 4. Length of the cycle and hand yield of 'Prata-Anã' banana plants grown at different plant densities $(1,666$; 2,$083 ; 2,666$ and 3,333 plants ha $\left.{ }^{-1}\right)$, irrigation levels (100, 75 and 50\% of crop evapotranspiration (ETc), and production cycles (mother- and daughter-plant). Note: number of days to harvest (A), yield (B). **significant at $1 \%$ significance level based on a t-test.

When plant density is raised from 1,666 plants ha ${ }^{-1}$ to 3,333 plants $^{-1}{ }^{-1}$, the number of days to harvest linearly increased with increasing plant density, ranging from 383.66 to 402.21 days in the first cycle, and from 640.02 to 709.26 days in the second cycle, 4.85 and $10.82 \%$, respectively (Figure 4B). The results are consistent with those reported by Santos et al. (2019), and indicate that the lengthening of the cycle is a consequence of increased plant density, and such effect tends to be more pronounced in later cycles (PEREIRA et al., 2000).

The irrigation level $\mathrm{x}$ plant density $\mathrm{x}$ production cycle interaction significantly affected WUE. A surface response model was fitted to WUE data, which increased linearly with increasing plant density and decreased with increasing irrigation level; the production cycles were graphed separately (Figure 5). The highest WUE of 34.33 and $35.54 \mathrm{~kg} \mathrm{ha}^{-1} \mathrm{~mm}^{-1}$ were observed when using $50 \%$ ETc irrigation level and 3,333 plants $\mathrm{ha}^{-1}$ in the first and second production cycle, respectively. These increases in WUE of $313.92 \%$ for the first cycle and of $295.27 \%$ in the second cycle corresponded to increasing from 8.29 to
$34.33 \mathrm{~kg} \mathrm{ha}^{-1} \mathrm{~mm}^{-1}$ and from 8.99 to $35.54 \mathrm{~kg} \mathrm{ha}^{-1} \mathrm{~mm}^{-1}$, respectively.

The results might be associated with the fact that higher plant densities in semiarid regions protect the plants from strong winds and excessive radiation, improve sensible heat transfer, and reduce soil water loss through evaporation (DONATO et al., 2015). These responses contribute to the improvement of plant physiological processes including carboxylation of rubisco (ARANTES et al., 2016; RAMOS et al., 2018) and plant water use (ARANTES et al., 2018), with further increases in net photosynthesis and yield; hence, using less irrigation water is a feasible option, with gains in yield and WUE.

Although higher plant densities provide higher yields per unit area using less water, smaller fruits might negatively affect fruit marketability and profits; thus, fruit size plays an important role in selecting the plant population density. 

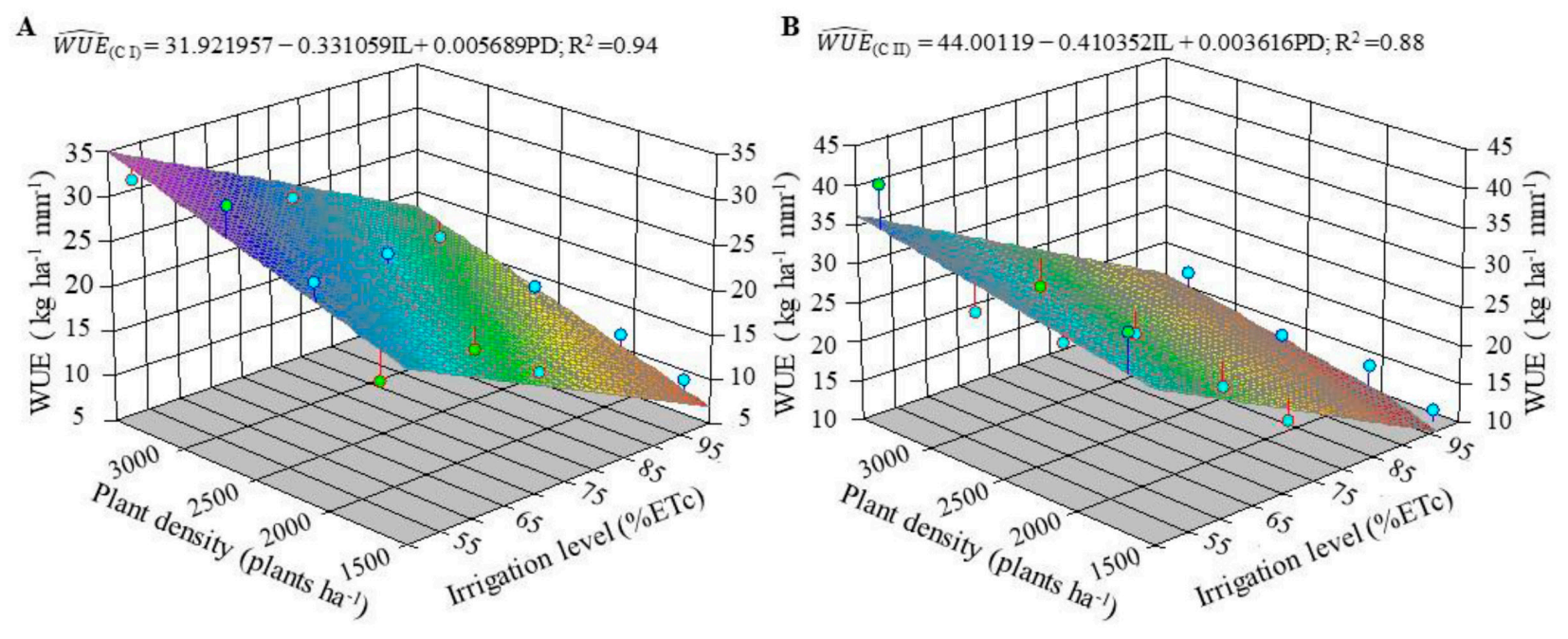

Figure 5. Water-use efficiency in 'Prata-Anã' grown at different plant densities $(1,666 ; 2,083 ; 2,666$ and 3,333 plants $\mathrm{ha}^{-1}$ ), irrigation levels (100, 75 and 50\% of crop evapotranspiration (ETc), and production cycles (mother- and daughterplant). Note: water-use efficiency in the first production cycle (A) and water-use efficiency in the second production cycle (B).

Number of leaves at harvest, mean fruit weight, outer fruit length, fruit diameter and WUE were influenced by irrigation level $\mathrm{x}$ production cycle interaction (Table 2). Plant density, however, had no effect on outer fruit length. Fruits were longer at 50\% ETc irrigation level than at $100 \%$ ETc. Fruit diameter measured in the first cycle differed from that measured in the second cycle, but irrigation levels had no effect on it. It can be inferred from these results that neither increasing plant density nor reducing irrigation levels affects negatively fruit size based on standards for Prata-type bananas (PBMH; PIF, 2006), which must be at least $14 \mathrm{~cm}$ long and $32 \mathrm{~mm}$ in diameter. Therefore, based on that, increasing plant densities or reducing irrigation levels or both are recommended for 'Prata-Anã' banana plants grown in conditions similar to those of this study.

Table 2. Mean vegetative traits and yield measured in the first and second production cycle of 'Prata-Anã' banana plants grown at different plant densities $\left(1,666 ; 2,083 ; 2,666\right.$ and 3,333 plants ha $\left.^{-1}\right)$, irrigation levels $(100,75$ and 50\% of crop evapotranspiration (ETc), and production cycles (mother- and daughter-plant).

\begin{tabular}{|c|c|c|c|c|c|c|c|c|c|c|}
\hline \multirow{2}{*}{$\begin{array}{c}\text { Irrigation } \\
\text { levels }\end{array}$} & \multicolumn{2}{|r|}{$\begin{array}{c}\text { NLH } \\
\text { (un) }\end{array}$} & \multicolumn{2}{|r|}{$\begin{array}{l}\text { MFW } \\
(\mathrm{g})\end{array}$} & \multicolumn{2}{|c|}{$\begin{array}{l}\text { FLH } \\
(\mathrm{cm})\end{array}$} & \multicolumn{2}{|c|}{$\begin{array}{l}\text { FDM } \\
(\mathrm{mm})\end{array}$} & \multicolumn{2}{|c|}{$\begin{array}{c}\text { WUE } \\
\left(\mathrm{kg} \mathrm{ha}^{-1} \mathrm{~mm}^{-1}\right)\end{array}$} \\
\hline & Cycle I & Cycle II & Cycle I & Cycle II & Cycle I & Cycle II & Cycle I & Cycle II & Cycle I & Cycle II \\
\hline $100 \% \mathrm{ETc}$ & $13.90 \mathrm{bA}$ & $10.20 \mathrm{abB}$ & $124.48 \mathrm{bA}$ & $108.18 \mathrm{bB}$ & $15.48 \mathrm{bA}$ & $16.02 \mathrm{bA}$ & $36.06 \mathrm{bA}$ & $34.78 \mathrm{aB}$ & $12.47 \mathrm{cA}$ & $13.33 \mathrm{cA}$ \\
\hline 75 & $14.99 \mathrm{aA}$ & $9.86 \mathrm{bB}$ & $137.89 \mathrm{aA}$ & $104.64 \mathrm{bB}$ & $16.59 \mathrm{aA}$ & 15.9 & $38.14 \mathrm{aA}$ & $34.50 \mathrm{aB}$ & $20.05 \mathrm{bA}$ & 18.9 \\
\hline $50 \%$ ETc & $15.23 \mathrm{aA}$ & $10.33 \mathrm{aB}$ & $133.20 \mathrm{aA}$ & $117.50 \mathrm{aB}$ & $16.49 \mathrm{aA}$ & $16.79 \mathrm{aA}$ & $37.89 \mathrm{aA}$ & $35.22 \mathrm{aB}$ & $29.02 \mathrm{aB}$ & $33.85 \mathrm{aA}$ \\
\hline Mean & 14.71 & 10.13 & 131.86 & 110.11 & 16.19 & 16.24 & 37.36 & 34.83 & 20.51 & 22.04 \\
\hline CV (\%) & & 7.43 & & 12.47 & 5. & & & & & .17 \\
\hline
\end{tabular}

NLH, number of leaves at harvest; MFW, mean fruit weight; FLH, outer fruit length; FDM, fruit diameter; WUE, water-use efficiency; CV, coefficient of variation. Means followed by the same letter, uppercase in a column and lowercase in a row, do not differ from one another based on the Tukey test at 5\% significance level.

The number of leaves at harvest in the first production cycle was higher than that in the second cycle for every irrigation level tested. This may be explained by the fact that the harvest of the first cycle took place between 383 and 402 DAP, between January and February 2018 — during the rainy season —, whereas the harvest of the second cycle occurred between 640 and 709 DAP, that is, between September and November 2018, peaking in October, which is characterized by maximum temperatures above $34^{\circ} \mathrm{C}$, often reaching up $38^{\circ} \mathrm{C}$. High temperatures are associated with excessive radiation, low humidity, intense winds, and drought. The combined effect of these stresses hinders growth, development and yield of banana plants, even when irrigated (DONATO et al., 2016). The lower number of leaves in the second cycle may be a result of leaves falling off following flowering due to plant senescence and tears caused by strong winds that often occur from May to October in the region, coincident with period between flowering and harvest of the second production cycle. 
The highest WUE was attained when applying a irrigation level of $50 \% \mathrm{ETc}$, which resulted in a higher WUE in the second production cycle compared with the first cycle (Table 2). When reducing the irrigation level from $100 \%$ to $50 \% \mathrm{ETc}$, both in the first and second cycle, WUE increased by 132.72 and $153.94 \%$, respectively. As yields were statistically similar across irrigation levels, using the lowest irrigation level resulted in the highest WUE.
Plant height at flowering, LAI, hand weight, number of hands, number of fruits and yield of 'Prata-Anã' banana plants were higher in the second cycle than in the first cycle (Table 3). This is consistent with the notion that Prata-type bananas have higher yields in the second production cycle (ARANTES et al., 2017; MARQUES et al., 2018) owing to more vigorous plants at flowering and increased LAI. Furthermore, it is generally expected that banana yield keeps on increasing up to the fourth production cycle, after which it stabilizes; however, vegetative traits and yields are more contrasting between the first and second production cycles, mother- and daughter-plant cycles (MARQUES et al., 2011; 2018; ARANTES et al., 2017).

Table 3. Mean vegetative traits and yields measured at flowering and harvest of the first and second production cycle of 'Prata-Anã' banana plants grown at different plant densities $\left(1,666 ; 2,083 ; 2,666\right.$ and 3,333 plants ha $\left.^{-1}\right)$, irrigation levels (100, 75 and 50\% of crop evapotranspiration (ETc), and production cycles (mother- and daughter-plant).

\begin{tabular}{lcccccc}
\hline \multirow{2}{*}{ Production cycle } & PHF & LAI & HAW & NHA & NFR & YIELD \\
\cline { 2 - 7 } & $(\mathrm{cm})$ & $\left(\mathrm{m}^{2} \mathrm{~m}^{-2}\right)$ & $(\mathrm{kg})$ & $(\mathrm{un})$ & $(\mathrm{un})$ & $\left(\mathrm{t} \mathrm{ha}^{-1}\right)$ \\
\hline Cycle I & $236.89 \mathrm{~b}$ & $3.67 \mathrm{~b}$ & $14.59 \mathrm{~b}$ & $8.08 \mathrm{~b}$ & $116.04 \mathrm{~b}$ & $35.02 \mathrm{~b}$ \\
Cycle II & $330.32 \mathrm{a}$ & $4.26 \mathrm{a}$ & $16.42 \mathrm{a}$ & $10.12 \mathrm{a}$ & $159.77 \mathrm{a}$ & $39.39 \mathrm{a}$ \\
\hline Mean & 283.60 & 3.96 & 15.50 & 9.10 & 137.90 & 37.20 \\
\hline CV $(\%)$ & 4.16 & 7.68 & 12.57 & 4.92 & 7.07 & 13.30 \\
\hline
\end{tabular}

PHF, plant height at flowering; LAI, leaf area index; HAW, hand weight; NHA, number of hands; NFR, number of fruits; CV, coefficient of variation. Means followed by the same letters in a column do not differ from one another based on the F-test at 5\% significance level.

Hand yields increased with increasing plant density and did not differ with irrigation level. This means that a higher plant population density coupled with a lower irrigation level leads to increases in yield and WUE in the first and second production cycles of 'Prata-Anã' banana plants, without decreasing fruit size; however, this hypothesis should be also tested in later cycles.

\section{Conclusions}

Increasing plant density of 'Prata-Anã' banana plants up to 3,333 plants ha-1 induced increases in the number of leaves at harvest, bunch weight, hand weight, number of hands, number of fruits, and mean fruit weight; cycles becomes longer, but yields increase without compromising fruit marketable size, regardless of the irrigation level used.

Increasing plant density from 1,666 to 3,333 plants $\mathrm{ha}^{-1}$ and reducing irrigation level from 100 to $50 \% \mathrm{ETc}$ lead to increases in water-use efficiency of $313.92 \%$ for the first cycle and $295.27 \%$ for the second cycle, which correspond to going from 8.29 to $34.33 \mathrm{~kg} \mathrm{ha}^{-1} \mathrm{~mm}^{-1}$ and from 8.99 to $35.54 \mathrm{~kg} \mathrm{ha}^{-1} \mathrm{~mm}^{-1}$, respectively.

It is possible to obtain higher yields and water-use efficiency with a plant density of up to 3,333 plants ha ${ }^{-1}$ and irrigation level below 100\% ETc.

\section{References}

ALLEN, R.G.; PEREIRA, L.S.; RAES, D.; SMITH, M. Crop evapotranspiration. Guidelines for computing crop water requirements. Rome: FAO, 1998. 300p. (Irrigation and drainage, 56).

ARANTES, A,M.; DONATO, S.L.R.; SILVA, T.S.; RODRIGUES FILHO, V.A.; AMORIM, E.P. Agronomic evaluation of banana plants in three production cycles in southwestern state of Bahia. Revista Brasileira de Fruticultura, Jaboticabal, v.39, n.1, p.1-12, 2017.

ARANTES, A.M.; DONATO, S.L.R.; SIQUEIRA, D.L.; COELHO, E.F. Gas exchange in 'Pome' banana plants grown under different irrigation systems. Engenharia Agrícola, Jaboticabal, v.38, n.2, p.197-207, 2018.

ARANTES, A.M.; DONATO, S.L.R.; SIQUEIRA, D.L.; COELHO, E.F.; SILVA, T.S. Gas exchange in diferente varieties of banana prata in semi-arid environment.

Revista Brasileira de Fruticultura, Jaboticabal, v.38, n.2, p.1-12, 2016. 
BORGES, A.L.; COELHO, E.F.; COSTA, E.L.; TEIXEIRA, A.H.C. In: SOUZA, V.F.; MAROUELLI, W.A.; COELHO, E.F.; PINTO, J.M.; COELHO FILHO, M.A. Irrigação e fertirrigação em fruteiras e hortaliças. Brasília: Embrapa Informação Tecnológica, 2011. p.369397.

CAVALCANTE, M.J.B.; ANDRADE NETO, R.C.; LEDO, A.S.; GONDIM, T.M.S.; CORDEIRO, Z.J.M. Manejo fitotécnico da bananeira, cultivar D'Angola (AAB), visando ao controle da sigatoka-negra. Revista Caatinga, Mossoró, v.27, n.2, p.201-208, 2014.

COELHO, E.F.; SANTOS, M.R; DONATO, S.L.R.; CRUZ, J.L.; OLIVEIRA, P.M.; CASTRICINI, A. Soilwater-plant relationship and banana yield under partial root-zone drying irrigation. Scientia Agricola, Piracicaba, v.76, n.5, p.362-367, 2019.

DONATO, S.L.R.; COELHO, E.F.; MARQUES, P.R.R.; ARANTES, A.M. Considerações ecológicas, fisiológicas e de manejo. In: FERREIRA, C.F.; SILVA, S. de O. e; AMORIN, E.P.; SANTOS-SEREJO, J.A. dos. O agronegócio da banana. Brasília: Embrapa Mandioca e Fruticultura, 2016. cap. 3, p.45-110.

DONATO, S.L.R.; COELHO, E.F.; SANTOS, M.R.; ARANTES, A.M.; RODRIGUES, M.G.V. Eficiência de uso da água em bananeira. Informe Agropecuário, Belo Horizonte, v.36, n.288, p.46-61, 2015.

EMBRAPA - Empresa Brasileira de Pesquisa Agropecuária. Sistema brasileiro de classificação de solos. 3.ed. Brasília, 2013. 353p.

LANZA, T.R.; MACHADO, A.F.L.; MARTELLETO, L.A.P. Effects of planting densities of 'BRS Princess' banana tree in the suppression weeds. Planta Daninha, Viçosa, MG, v.35, p.e017162958, 2017.

MARQUES, P.R.R.; DONATO, S.L.R.; PEREIRA, M.C.T.; COELHO, E.F.; ARANTES, A.M. Características agronômicas de bananeiras tipo Prata sob diferentes sistemas de irrigação. Pesquisa Agropecuária Brasileira, Brasília, DF, v. 46, p. 852-859, 2011.

MARQUES, P.R.R.; DONATO, S.L.R.; SÃO JOSÉ, A.R.; ARANTES, A.M.; ROSA, R. C.C. Gas exchange and yield of Prata-type banana plants with fertilizer sources for organic management. African Journal of Agricultural Research, Nairobi, v.13, n.5, p.272-280, 2018.
OLIVEIRA. J.M.; COELHO FILHO, M.A.; COELHO, E.F. Crescimento da bananeira Grande Naine submetida a diferentes lâminas de irrigação em tabuleiro costeiro. Revista Brasileira de Engenharia Agrícola e Ambiental, Campina Grande, v.17, n.10, p.1038-1046, 2013.

PBMH/PIF - Programa Brasileiro para a Modernização da Horticultura e Produção Integrada de Frutas. Normas de classificação de banana. São Paulo: CEAGESP, 2006. (Documentos, 29).

PEREIRA, M.C.T.; SALOMÃO, L.C.C.; SILVA, S.D.O.; SEDIYAMA, C.S.; COUTO, F.A.D.; SILVA NETO, S.D. Crescimento e produção de primeiro ciclo da bananeira 'Prata Anã' (AAB) em sete espaçamentos. Pesquisa Agropecuária Brasileira, Brasília, DF, v.35, n.7, p.13771387, 2000.

PRATA, C.R.; SILVA, J.; LIMA, Y.B.; ANCHIETA, O.F.A.; DANTAS, R.P.; LIMA, M.B. Densidade de plantio no crescimento e produção de plátano cv. D’Angola na Chapada do Apodi. Revista Agropecuária Técnica, Areia, v.39, n.1, p.15-23, 2018.

RAMOS, A.G.O.; DONATO, S.L.R.; ARANTES, A.M.; COELHO FILHO, M.A.; RODRIGUES, M.G.V. Evaluation of gas exchanges and production of genotypes of Maçã banana type cultivated in the semi-arid region of Bahia. Revista Brasileira de Fruticultura, Jaboticabal, v.40, n3, e-500, 2018.

RODRIGUES, M.G.V.; DONATO, S.L.R.; LICHTEMBERG, L.A.; DIAS, M.S._Implantação e condução do bananal. Informe Agropecuário, Belo Horizonte, v.36, n.288, p.27-45, 2015.

RODRIGUES, M.G.V.; RUGGIERO, C.; NATALE, W.; PACHECO, D.D. Nutrição e produção da bananeira 'Prata-Ana' adubada com zinco e boro diretamente no rizoma, via muda desbastada. Revista Brasileira de Fruticultura, Jaboticabal, v.29, n.3, p.645-651, 2007.

ROSALES, F.E.; ALVAREZ, J.M. VARGAS, A. Guia prática para La producción de plátano con altas densidades - experiencias de América Latina y el Caribe. Montepellier: Bioversity Internacional, 2008.

SANTOS, M.R.; DONATO, S.L.R.; LOURENÇO, L.L.; SILVA, T.S.; COELHO FILHO, M.A. Irrigation management strategy for Prata-type banana. Revista Brasileira de Engenharia Agrícola e Ambiental, Campina Grande, v.20, n.9, p.817-822, 2016. 
SANTOS, M.R.; DONATO, S.L.R.; MAGALHÃES, D.B. ; COTRIM, M.P. Precocity, yield and water-use efficiency of banana plants under planting densities and irrigation depths, in semiarid region. Pesquisa Agropecuária Tropical, Goiânia, v.49, n.e53036, p.01-10, 2019.

SCARPARE FILHO, J.A.; KLUGE, R.A. Produção da bananeira 'Nanicão' em diferentes densidades de plantas e sistemas de espaçamento. Pesquisa Agropecuária Brasileira, Brasília, DF, v.36. n.1, p.105-113, 2001.
SILVA, J.T.A. da. Solo, adubação e nutrição para bananeira. Informe Agropecuário, Belo Horizonte, v.36, n.288, p.74-83, 2015.

TURNER, D.W.; FORTESCUE, J.A.; THOMAS, D.S. Environmental physiology of the bananas (Musa spp.). Brazilian Journal of Plant Physiology, Londrina, v.19, n.4, p.463-484, 2007.

ULLOA CORTAZAR, A.M.; WOLF, E.D.; GONZALEZ, I.A. Effect of plant density on growth and yield in Barraganete plantain (Musa paradisiaca (L.) AAB cv. Curare enano) for a single harvest cutting in Provincia de Los Ríos, Ecuador. Acta Agronómica, Bogotá, v.66, n.3, p.367-372, 2017. 